\title{
A molecular genetic approach for sex determination on helmeted hornbill (Rhinoplax vigil) casque: a forensic casework
}

\author{
Yuli S. Fitriana ${ }^{1}$, Mohammad Irham $^{1}$, Hari Sutrisno ${ }^{1}$, and Abinawanto $^{2, *}$ \\ ${ }^{1}$ Museum Zoologicum Bogoriense, Research Center for Biology - Indonesian Institute of Sciences, J1 Raya Jakarta-Bogor \\ KM. 46 Cibinong 16911, West Java, Indonesia \\ ${ }^{2}$ Department of Biology, Faculty of Mathematic and Natural Science, University of Indonesia, Kampus UI Gedung E 1t. 2, Jl. \\ Lingkar Kampus Raya, Pondok Cina, Kecamatan Beji, Kota Depok 16424, West Java, Indonesia
}

\begin{abstract}
Helmeted Hornbill (Rhinolax vigil) is the only hornbill that equipped with solid casque made from keratin for both males and females. The demand for casque in the black market was huge and resulted in IUCN status leaped up from vulnerable to critically endangered. We received a total of 68 confiscated helmeted hornbill casques. As part of the casework and the objectives of the study, we determined to reveal the sex status of those casques and the best methods to work with keratinous material. Molecular methods to determining sex in birds rely on the CHD gene located on male and female chromosomes $\mathrm{ZZ}$ and $\mathrm{ZW}$, respectively. We optimized laboratory protocols for genetic sexing using three independent sets of primers $\mathrm{P} 2 / \mathrm{P} 8,2550 \mathrm{~F} / 2718 \mathrm{R}$, and CHD1F/CHD1R to amplify regions of the sexlinked CHD-Z and CHD-W genes. The CHD1F/CHD1R determined sex $80.88 \%$ of samples. The $2550 \mathrm{~F} / 2718 \mathrm{R}$ were quite successful, sexing $51.47 \%$ of samples. In contrast, the $\mathrm{P} 2 / \mathrm{P} 8$ only identified the sex around $20.58 \%$ of samples. These results showed that CHD1F/CHD1R works the most effective for sexing the casques with $52.9 \%$ females, $27.9 \%$ males, and $19.1 \%$ unidentified. Therefore, the most accurate and suitable primers are CHD1F/CHD1R, 2550F/2718R, and P2/P8, respectively for keratinous samples.
\end{abstract}

\section{Introduction}

Helmeted Hornbill (Rhinoplax vigil) is one of the members from Bucerotidae family that distributed from extreme south Myanmar through Malay Peninsula, Sumatera and Borneo (including Indonesian Kalimantan; thus, politically speaking, this species is present at Myanmar, Thailand, Malaysia, Brunei, and Indonesia but is considered extinct in Singapore [1-2]. Helmeted Hornbill occupies the primary rainforest that is dominated by large dipterocarp vegetation with occasionally is found in old secondary forest. The diet of helmeted hornbill is consisting of small animals and fruits. However, fruit, especially figs, is the main diet of Helmeted hornbill that may consist of $60 \%$ from the entire diet [2-5]. The helmeted hornbill is monogamous breeding pairs so that the female is dependent on the male during the breeding season. They can produce two clutches but only one offspring will survive and fledge. Helmeted hornbill needs particular requirements for nest that are a natural cavity in large living tree and branch nearby that serve as a ledge for they can perch at the opening of the cavity [6].

The most unique character that only posses by Helmeted Hornbill is the casque. Unlike the other species of hornbill, the casque of Helmeted hornbill is made from solid keratin while the casque of the other species are light and spongy [7]. The color of helmeted hornbill casque is primarily a solid yellowish-white to whitish-yellow material with a very thin outer covering that is an intense brownish-red. The material of casque showed a hardness of approximately 2.5 (Mohs Scale), a specific gravity of approximately 1.28 , and a refractive index of approximately 1.55; and it reacts to a fluorescence that ranges from greenish-white to bluishwhite under ultraviolet light, and it does not react to hydrochloric acid [8].

Due to that unique characteristics, helmeted hornbill casque has been used for carving materials for decorative and antiquities since the Tang Dynasty (618-907 A.D) [8]. Although internationally this species is fully protected from trade activity as it is listed in Appendix I CITES, the demand for the materials still exists. The illegal trade has increased for the last ten years at the least. There were about 500 adults were killed in Kalimantan in 2013 and the authorities have confiscated more than 1.100 casques en route to China [9]. The other records showed that between March 2012 and August 2014 the authority successfully confiscated around 2,170 heads and/or casques, and a total of 1,117 specimens

\footnotetext{
* Corresponding author: abinawanto.m@sci.ui.ac.id
} 
were confiscated from thirteen seizures [10]. The threat is very high and imminent for helmeted hornbill, and considering the slow reproductive stages and shrinking habitat; helmeted hornbill becomes one of the species that the IUCN red list status jumped from Near Threatened to Critically Endangered in 2015 [11].

Despite being protected under Indonesian legislation, illegal poaching and trading of helmeted hornbill continue and numbers remain low across the distribution area. To establish a reliable forensic tool for use in cases of illegal persecution and conservation program, there is a need for DNA-based on the geographic origin population identification and sexing system. Reliable methods for the sex-determining of birds in laboratory and field studies provide essential information in demographics that are required for many questions in evolutionary biology and ecology. Molecular methods for sex determination are a useful tool and have been applied to studies of sex ratio evolution and species mating systems assesment [12-14], characteristics of sex-specific life history [15-17], improvement of captive breeding programs $[14,18,19]$, management of wildlife species, analysis of breeding strategies in commercial poultry, population, behaviour, evolutionary, and forensic studies [14].

The development of molecular sexing assays for all neognath (nonratite) birds $[20,21]$ is now applied routinely to determine sex in extant populations, and it has greatly enhanced the study of avian biology. PCR amplification of the sex-linked chromohelicase DNAbinding protein 1 (CHD 1) gene has most commonly used for molecular sexing in non-ratite birds [22]. The primers within conserved exons will amplify across introns with differ in size on the avian sex chromosomes ( $\mathrm{Z}$ and $\mathrm{W})$, producing amplicons in the region of $300-$ $400 \mathrm{bp}$ for $Z$ chromosome [20] and 400-700 bp for $\mathrm{W}$ chromosome [21], respectively. The different sizes of amplicons between $\mathrm{Z}$ and $\mathrm{W}$ chromosomes can be used to determine the sex of male and female birds. The females being heterogametic (ZW) display by two bands in different sizes, while males being homogametic (ZZ) display by one band, upon size separation [20, 22]. However, sometimes the amplification across the intron failed to produce size differences due to allele dropout, especially with degraded samples. There are several independently developed primer sets are utilized for sexing birds using DNA; particularly, 3 such sets are commonly used; The P2/P8 [20], 2550F/2718R [21], and CHD1F/CHD1R [23].

So far, there is no detail information on the status of confiscated casques such as the sex, the geographical origin, and the ages of helmeted hornbill. That information is critical for law enforcement and conservation strategies to prevent further persecution on this hornbill. In 2017 we have received the confiscated casques from the authorities and attempted to investigate the status of casques. We could confirm that the objects were helmeted hornbill. The subsequent objectives will be to examine the sex status and geographical origin. In this paper, we will explain the sex status of some of the casques that we have successfully analyzed by comparing the 3 primer sets and optimizing the protocol for the success rate of sexing birds using keratinous material.

\section{Material and Methods}

A total of 68 casques of Helmeted hornbill were used in the study. We used 22 blood samples and feather samples from 2 individuals of Bali mynah for comparison. Permission to collect tissue samples from the confiscated casque of helmeted hornbill was approved by The Ministry of Environment and Forestry of Indonesia. The tissue samples were available from the confiscated specimens of helmeted hornbill casque. DNA was isolated from keratinous material of hornbill's casque using QIAamp DNA Investigator Kit (Qiagen, Germany) following manufacturer's instructions and quantified using spectrophotometer Thermo Scientific ${ }^{\mathrm{TM}}$ NanoDrop ${ }^{\mathrm{TM}}$ One Microvolume UV vis for PCR purposes only.

Three primer sets CHD1F/CHD1R, 2550F/2718R, and P2/P8 were used to amplify fragments of the CHD gene (Table 1.). PCR was carried out in $10 \mu \mathrm{l}$ volume containing 20-40 ng DNA, 1X HotStarTaq Plus PCR Mastermix (Qiagen, Germany), and $0.5 \mu \mathrm{M}$ of each primer. PCR cycling condition was as follows; $94^{\circ} \mathrm{C}$ for $2 \mathrm{~min}$, then 10 cycles of $94^{\circ} \mathrm{C}$ for $30 \mathrm{~s}, 54^{\circ} \mathrm{C}$ for $15 \mathrm{~s}$ and $72^{\circ} \mathrm{C}$ for $30 \mathrm{~s}$, followed by 30 cycles of $94^{\circ} \mathrm{C}$ for $30 \mathrm{~s}$, $50^{\circ} \mathrm{C}$ for $30 \mathrm{~s}$ and $72^{\circ} \mathrm{C}$ for $30 \mathrm{~s}$, and finally $72^{\circ} \mathrm{C}$ for 5 min modified from [24]. The PCR cycling for P2/P8 was $94^{\circ} \mathrm{C}$ for 4 min for initial incubation, followed by 40 cycles at $94^{\circ} \mathrm{C}$ for $30 \mathrm{~s}, 51^{\circ} \mathrm{C}$ for $45 \mathrm{~s}$, and $72^{\circ} \mathrm{C}$ for 45 $\mathrm{s}$, and further extension at $72^{\circ} \mathrm{C}$ for $5 \mathrm{~min} \mathrm{[25].}$

Table 1. The sequences of the 3 primer pairs compared in the current study.

\begin{tabular}{lll}
\hline Primer name & Primer sequence (5'-3') & Reference \\
\hline CHD1 F & TATCGTCAGTTTCCTTTTCAGGT & Lee et al. 2010 \\
CHD1 R & CCTTTTATTGATCCATCAAGCCT & \\
$2550 \mathrm{~F}$ & GTTACTGATTCGTCTACGAGA & Fridolfsson \& Ellegren 1999 \\
$2718 \mathrm{R}$ & ATTGAAATGATCCAGTGCTTG & \\
P2 & TCTGCATCGCTAAATCCTTT & Griffiths et al. 1998 \\
P8 & CTCCCAAGGATGAGRAAYTG & \\
\hline
\end{tabular}


For amplification of $2550 \mathrm{~F} / 2718 \mathrm{R}$ we used a touchdown scheme where annealing temperature was reduce $1^{\circ} \mathrm{C}$ per cycle, starting from $57^{\circ} \mathrm{C}$ until it reached $50^{\circ} \mathrm{C}$, followed by 30 cycles, and final extension at $74^{\circ} \mathrm{C}$ for $5 \mathrm{~min}$ [25]. Agarose gel electrophoresis (2\%) and fluorosafe staining were subsequently carried out to visualize the products.

\section{Results and Discussion}

The fragment of the CHD gene was amplified using CHD1F/CHD1R, 2550F/2718R, and P2/P8 primer sets to determine the sex of individuals from 68 Helmeted hornbill casques. All primers can work with keratinous material, although the performance of each primer is shown differently (Table 2). CHD1F/CHD1R works the most effective for sexing the casques with $52.9 \%$ females, $27.9 \%$ males, and $19.1 \%$ unidentified. Meanwhile, the other two primers worked less accurately with more unidentified sexes, including the misidentified sexes.

Table 2. Sexing success rates of the 3 primer sets in 68 keratinous casques of Helmeted Hornbill, feather and blood samples of Bali mynah.

\begin{tabular}{|c|c|c|c|c|c|}
\hline & $\mathbf{M}$ & $\mathbf{F}$ & MI & $\mathbf{U}$ & $\begin{array}{c}\text { SR } \\
(\%)\end{array}$ \\
\hline \multicolumn{6}{|l|}{ Casques } \\
\hline CHD1F/CHD1R & 19 & 36 & 0 & 13 & 80.88 \\
\hline $2550 \mathrm{~F} / 2718 \mathrm{R}$ & 11 & 24 & 5 & 28 & 51.47 \\
\hline $\mathrm{P} 2 / \mathrm{P} 8$ & 5 & 11 & 14 & 38 & 20.58 \\
\hline \multicolumn{6}{|l|}{ Blood } \\
\hline CHD1F/CHD1R & 21 & 1 & 0 & 0 & 100 \\
\hline $2550 \mathrm{~F} / 2718 \mathrm{R}$ & 21 & 1 & 0 & 0 & 100 \\
\hline $\mathrm{P} 2 / \mathrm{P} 8$ & 9 & 0 & 7 & 6 & 40.90 \\
\hline \multicolumn{6}{|l|}{ Feathers } \\
\hline CHD1F/CHD1R & 1 & 1 & 0 & 0 & 100 \\
\hline $2550 \mathrm{~F} / 2718 \mathrm{R}$ & 1 & 1 & 0 & 0 & 100 \\
\hline $\mathrm{P} 2 / \mathrm{P} 8$ & 0 & 0 & 1 & 1 & 0 \\
\hline
\end{tabular}

It was possible to compare the success rates of molecular sexing of Helmeted hornbill keratinous casques samples using 3 CHD-related primer pairs $\mathrm{CHD} 1 \mathrm{~F} / \mathrm{R}$ [23], 2550F/2718R [21], and P2/P8 [20] (Table 2). Sexing the same specimen with 3 different primer sets would avoid potential errors in interpreting sex-typing data, such as $\mathrm{Z}$ polymorphism [27] and the formation of heteroduplex DNA molecules [24]. According to agarose gel electrophoresis, the success rates of 3 different primer sets in keratinous casque samples of Helmeted hornbill were $80,88 \%, 51.47 \%$, and $20.58 \%$ for CHD1F/CHD1R. 2550F/2718R, and P2/P8, respectively. In addition all identified specimens are confirmed for both males and females by three primers. CHD1F/R successfully identified all specimens that were misidentified by $2550 \mathrm{~F} / \mathrm{R}$ and $\mathrm{P} 2 / \mathrm{P} 8$. Many of unidentified specimens by $2550 \mathrm{~F} / \mathrm{R}$ and $\mathrm{P} 2 / \mathrm{P} 8$ can be amplified with $\mathrm{CHD} 1 \mathrm{~F} / \mathrm{R}$. Therefore, we find that the rest of the 13 specimens are difficult to amplify by all primers.
We used blood samples and fresh feathers of Bali mynah for comparison. Similarly, according to agarose gel electrophoresis, the success rates of primer sets CHD1F/CHD1R, 2550F/2718R, and P2/P8 were $100 \%$ $(\mathrm{n}=22), 100 \%(\mathrm{n}=22)$, and $40.90 \%(\mathrm{n}=22)$ for blood samples; $100 \%(\mathrm{n}=2), 100 \%(\mathrm{n}=2)$, and $0 \%(\mathrm{n}=2)$ for feather samples. This can be directly related to the fact that DNA in feather samples generally submit lower copy numbers than DNA obtained from blood [25] and it occurs for keratinous samples also. Another possibility is perhaps DNA from feather and keratinous samples may get more easily degraded [25], so the quality and quantity of DNA extracted from feather and keratinous material would be correspondingly low. Another study reported that the polymorphic nature of the intron length, along with the power of variability in electrophoresis resolution, does not allow for accurate sex identification in some species of bird $[14,20,26]$. The use of denaturing acrlamide gels instead of agarose gels increasesthe resolution of electrophoresis [26] but in this study we did not carry out this procedure. The intraspecific variations at the CHD1Z homologues causing difficulties in CHD1-based molecular sexing. These polymorphism were detected in the intronic region amplified by primers P2/P8 [14, 27, 28, 29].

The result of CHD1F/CHD1R PCR products on $2 \%$ agarose gel generally showed a definite single band in males (CHD1-Z) and 2 bands in females (CHD1-Z and CHD1-W). In contrast, the amplification reactions performed with $\mathrm{P} 2 / \mathrm{P} 8$ and $2550 \mathrm{~F} / 2718 \mathrm{R}$ primer sets showed distinct banding patterns and failed to amplify the target gene (Figure 1). In some cases, both males and females presented a single band identical or different in size. It can be occurred due to an extremely short difference in intronic length between CHD-Z and CHD$\mathrm{W}$ in $\mathrm{P} 2 / \mathrm{P} 8$ amplicon which makes sex determination more difficult and inaccurate [30-32].

The ambiguous results may arise from the nucleotide diversity, using two primer pairs can resolve this problem. However, varied PCR conditions and gel concentrations were used to suit different species [26]. [20] reported the homologs of $\mathrm{Z}$ and $\mathrm{W}$ are sometimes similar size fragments in the case of the $\mathrm{P} 2 / \mathrm{P} 8$ primers. Another possibility of the single allele display in both sexes is the failure of the $\mathrm{W}$ locus to amplify probably due to primer-chromosome base mismatches [33]. There are molecular sexing errors detected both in P2/P8 and $2550 \mathrm{~F} / 2718 \mathrm{R}$ primers due to allelic dropout, where females are misidentified as male (single allele display in female) $[34,35]$.

The comparison of sexing results between various samples (casque, feather, and blood) using CHD1F/CHD1R primers on a simple $2 \%$ agarose gel shows in Figure 2. The $\mathrm{CHD} 1 \mathrm{~F} / \mathrm{CHD} 1 \mathrm{R}$ primers successfully amplified in 3 various samples and the results of PCR product showed a definite single band in males (CHD1-Z) and 2 bands in females (CHD1-Z and CHD1-W) in almost all samples. In some cases of keratinous samples, females presented a single band but 


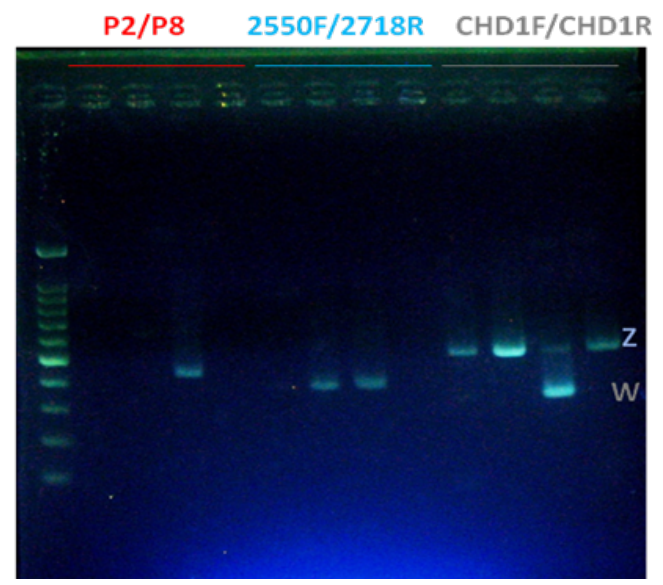

Fig 1. General banding patterns of 3 primer sets (CHD1F/CHD1R, 2550F/2718R, P2/P8) in Helmeted hornbill casques. Male $(\mathrm{ZZ})=1$ band; Female $(\mathrm{ZW})=2$ bands; ladder $=100 \mathrm{bp}$
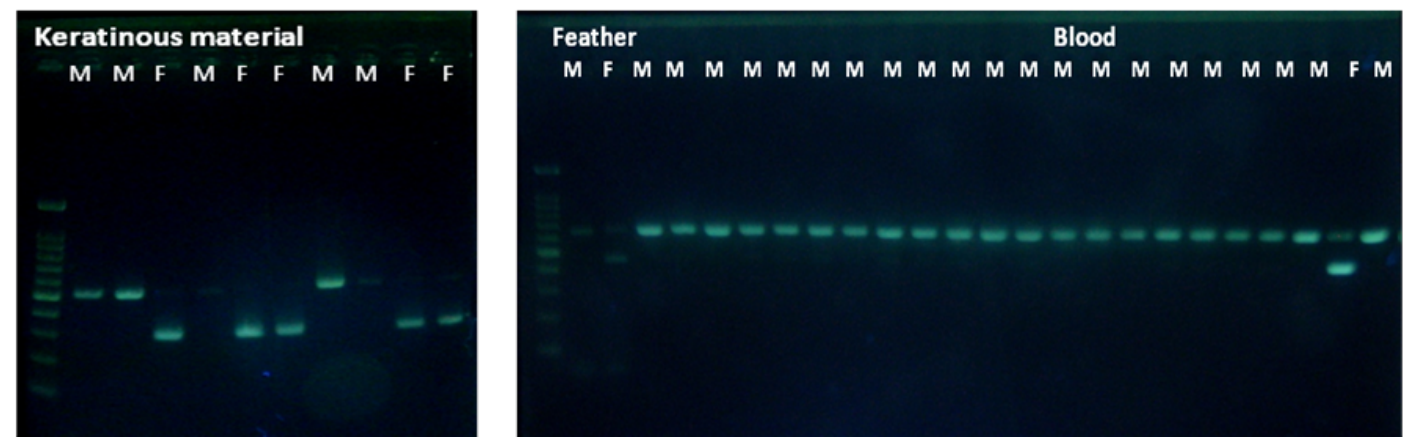

Fig 2. Comparison of sexing results with CHD1F/CHD1R primers between keratinous material (Casques), feather and blood samples. $\mathrm{M}=$ Male; $\mathrm{F}=$ Female

it located in the CHD1-W amplicon position (around 300-400 bp). The different size between CHD1-Z and CHD1-W amplicon of the avian sex chromosomes is fquiet high whereas the $\mathrm{Z}$ chromosomes producing amplicon in the region of 400-700 bp [20] and 400-700 bp in $\mathrm{W}$ chromosomes amplicon [21]. Based on it we can identify the sample with a single band located in the region around 300-400 bp as female, confidently.

PCR amplification with CHD gene-based proved to be reliable, generally accurate, and satisfactory technique for sex determination of Helmeted hornbill with keratinous samples. Among 3 primer sets studied, CHD1F/CHD1R and 2550F/2718R were able to determine the sex of birds with various samples, whereas P2/P8 was only partially successful. However, it might be necessary to carry out an additional technique of fragment analysis to get the best result, but it increases costs associated with the procedure. Overall, DNA sexing of birds with 3 primer sets can be used for keratinous material, but we recommend a preliminary comparison of those primer sets for efficiency and effectiveness before molecular sexing of large numbers of specimens or variety of samples.

\section{Conclusion}

The molecular sexing assays with PCR amplification of the sex-linked chromohelicase DNA-binding protein 1 (CHD 1) gene using 3 primer sets can be applied for keratinous material such as the casques of Helmeted Hornbill. The primer sets should be compared before choosing the most efficient one for molecular sexing of keratinous or degraded materials. Among 3 primer sets studied, the CHD1F/CHD1R are the most suitable primers to amplified both CHD-Z and CHD-W amplicon from keratinous material.

We thank the Enforcement Directorate General of Environment and Forestry, Ministry of Environment and Forestry of Republic Indonesia that provide the permit to using confiscated specimens for research. This research was fully funded by Research Center for Biology under the National Priority Research Project No.02.002. Scientific Recommendation on CITES Wildlife Trade 2018-2019. Yuli S. Fitriana and Mohammad Irham are equally contributed. 


\section{References}

1. J.A.S. Buchnill, F.N. Chasen, The birds of Singapore island (the Govt. Print. Office, Singapore, 1927) https://doi.org/10.5962/bhl.title.101719

2. A.C. Kemp, C.J. Sharpe \& P. Boesman, In del Hoyo, J., Elliott, A., Sargatal, J., Christie, D.A. \& de Juana, E. (eds.), Handbook of the Birds of the World Alive (Lynx Edicions, Barcelona, 2019) (retrieved from https://www.hbw.com/node/55911 on 15 November 2019)

3. P. Poonswad, A.C. Kemp, M. Strange. Hornbills of the World: A Photographic Guide (Draco Publishing and Hornbill Research Foundation, Thailand, 2013)

4. S. Kitamura, S. Thong-Aree, S. Madsri, P. Poonswad, Raffles Bull. Zool. 24, 137-147 (2011)

5. Y.R. Hadiprakarsa, M.F. Kinnaird, Bird Conserv. Int. 14 (S1), S53-S62 (2004)

6. M.F. Kinnaird \& T.G. O'Brien. The ecology and conservation of Asian hornbills: farmers of the forest (University of Chicago Press, Chicago, 2007)

7. K.C. Lint, Zoonooz, 45, 4-17 (1972)

8. R.E. Kane, Gems Gemol. XVII, 96-97 (1981)

9. N.J. Collar, BirdingASIA, 24, 12-17 (2015)

10. C. Beastall, C. Shepherd. Y. R. Hadiprakarsa, D. Martyr, Bird Conserv. Int. 26 (2), 137-146 (2016)

11. A. Symes A. Global IUCN Red List for birds 2015 changes. https://globally-threatened-birdforums.birdlife.org/2015/10/global-iucn-red-list-forbirds-2015-changes/. [ 15 November 2019]. (2015)

12. M. Andersson, J. Wallander, L. Oring, E. Akst, J.M. Reed, R.C. Fleischer, J. Evol. Biol. 16 (3), 510-515 (2003)

13. T. Székely, I.C. Cuthill, S. Yezerinac, R. Griffiths, J. Kis, Behav. Ecol. 15 (1), 58-62 (2004)

14. F. Morinha, J.A. Cabral, E. Bastos, Theriogenology, 78 (4), 703-714 (2012)

15. J. Merilä, B.C. Sheldon, H. Ellegren. Mol. Ecol. 6 (12), 1167-1175 (1997)

16. R.J. Lopes, J.C. Marques, L. Wennerberg, J. Ornithol. 147 (2), 385-394 (2006)

17. M. Remisiewicz, L. Wennerberg, Ornis Fennica, 83 (1), 1 (2006)

18. R. Griffiths, B. Tiwari, Nature, 375 (6531), 454-454 (1995)

19. S.I. Jarvi, P.C. Banko, Pac. Conserv. Biol. 6 (1), 14$17(2000)$

20. R. Griffiths, M. C. Double, K. Orr, R. J. Dawson, Mol. Ecol. 7 (8), 1071-1075 (1998).

21. A.K. Fridolfsson, H. Ellegren, J. Avian Biol. 116-121 (1999)

22. H. Ellergren. Proceedings of the Royal Society of London. Series B: Biological Sciences, 263 (1377) 1635-1641 (1996)

23. J.C.I. Lee, L.C. Tsai, P.Y. Hwa, C.L. Chan, A. Huang, S.C. Chin, L.C. Wang, J.T. Lin, A. Linacre, H.M. Hsieh, Mol. Cell. Probes, 24 (1), 27-31 (2010)

24. A.E. Casey, K.L. Jones, B.K. Sandercock, S.M. Wisely, Mol. Ecol. Resour. 9 (1), 61-65 (2009)

25. E. Çakmak, Ç. Akın Pekşen, C.C Bilgin. J. Vet. Diagn. Invest. 29 (1), 59-63 (2017)
26. T. Jensen, F.M. Pernasetti, B. Durrant, Zoo Biol. 22 (6), 561-571(2003)

27. D.A. Dawson, S. Darby, F.M. Hunter, A.P. Krupa, I.L. Jones, T. Burke, Mol. Ecol. Notes, 1 (3), 201$204(2001)$

28. P.L. Lee, P.F. Brain, D.W. Forman, R.B. Bradbury, R. Griffiths, Evolution, 56 (12), 2548-2553 (2002)

29. J. Schroeder, R. Kentie, M. van der Velde, J.C. Hooijmeijer, C. Both, O. Haddrath, A.J. Baker, T. Piersma, Ibis, 152 (2), 368-377 (2010)

30. H. Ito, A. Sudo-Yamaji, M. Abe, T. Murase, T. Tsubota, Zool. Sci. 20 (3), 339-344 (2003)

31. H.W. Chang, T.C. Chou, D.L. Gu, C.A. Cheng, C.C. Chang, C.T. Yao, L.Y. Chuang, C.H. Wen, Y.C. Chou, K.Y. Tan, C.C. Cheng. Mol. Cell. Probes, 22 (3), 184-188 (2008)

32. L.C. Wang, C.T. Chen, H.Y. Lee, S.H. Li, J.T. Lir, S.C. Chin, C.E. Pu, C.H. Wang. Zoo Biol. 26 (5), 425-431 (2007)

33. D.A. Dawson, P. Brekke, N. Dos Remedios, G.J. Horsburgh. Conserv. Genet. Resour. 7 (2), 337-343 (2015)

34. K. E. Arnold, K. J. Orr, R. Griffiths, R. Mol. Ecol. 12(12), 3451-3458 (2003)

35. A. Henderson, C.M. Lee, V. Mistry, M.D. Thomas, A. Iyengar. J. Forensic Sci. 58 (2), 491-494 (2013) 